\title{
Holler László
}

\section{Baranyai Decsi János, a történetíró}

\section{Tisztelt Hölgyeim és Uraim!}

Az előző percekben felcsendült Palestrina-madrigálok és ez a gyönyörü gótikus terem korhü hangulatot és helyszínt nyújtanak ahhoz, hogy megemlékezzünk a 400 éve elhunyt polihisztor, Baranyai Decsi János történetírói müködéséről. Immár több mint kétszáz éve, hogy Kovachich Márton György 1798-ban nyomtatásban megjelentette Baranyai Decsi történeti emlékiratának az 1592 végétől 1594 végéig terjedő két év eseményeit tárgyaló részét, s azóta e mü az erdélyi történelem fontos és hiteles forrásának számít. A rendelkezésemre álló rövid időben szeretném vázolni azt az érdekes folyamatot, ahogy az évszázadok során ismereteink egyre gyarapodtak Baranyai Decsi János történetírói munkásságáról, és szeretnék egy-két szóban kitérni ezzel kapcsolatos saját kutatási eredményeimre is. Emellett müveiből és levelezéséből vett néhány idézettel szeretném felvillantani Decsi alakját, céljait, küzdelmeit és közelebb hozni Önökhöz a tudóst és az embert.

A legkorábbi mü, amelyben Decsi János történeti munkásságára vonatkozó utalás található, Rotharides 1745-ben kiadott latin nyelvü könyve a magyar irodalom történetéröl. ${ }^{1}$ Valójában csak a Kolozsváron, 1593-ban megjelent Syntagma institvtionum Jvris Imperialis ac Vngarici , azaz „A Birodalmi és Magyar Jog intézményeinek összehasonlítása” című művéről ír. Ismerteti ennek előszavát, majd így folytatja: „Arra is rászánta magát, hogy írjon egy általános magyar történelmet, de váratlan halála ebben megakadályozta, vagy talán a kéziratot valamely méltatlan kézre bízta, aki azt talán elherdálta vagy elásta, s így a tudós e gyümölcse nem láthatta meg a napvilágot - ezt nem tudom eldönteni."

Rotharides valójában nem tudott többet Decsi történeti munkájáról, mint amennyit a Syntagma elöszavából kihámozott. Ott ugyanis azt olvashatjuk: „...történelemírásunk tökéletesedéséhez az is megkívántatik, hogy minden, ebben a témakörben tevékenykedő írónak összes müvét és töredékét összegyüjtve, a teljes magyar történelem valósághüen, röviden és tisztán, a kezdetektől napjainkig egybefoglalva, rövid összefoglalás formájában megírattassék [...] Ezt a feladatot, ha akár nekem el szabad egyszer végeznem, ami már régóta foglalkoztat, és amin nem keveset fáradozom, vagy valaki más, akár akadályoztatásom miatt elvállalja vagy halálom miatt teljességre viszi, az illető minden bizonnyal nem csupán azok okulását szolgálja, akik a Bölcsesség tanaiban gyönyörködnek, hanem az egész hazának legszükségesebb és dicsőséges feladatát végzi el."

Ezekből a mondatokból már kiviláglik Baranyai Decsi történetírói koncepciója és elkötelezettsége a feladat iránt.

\footnotetext{
${ }^{1}$ Rotharides: Historiae Hvnqaricae Literariae Antiqvi Medii atqve Recentioris Aevi... Altonaviae et Servestae. MDCCXLV.

${ }^{2}$ Syntagma institvtionum Jvris Imperialis ac Vngarici. Kolozsvár 1593. (RMNY $719=$ RMK II. 241.)
} 
Bod Péter 1766-ban megjelent írói lexikonjában számos tényt ismertetett Decsi életéről, és négy mủvét említi. ${ }^{3}$ Történeti munkájáról a következőket írja: „Le-írta Magyar országnak is Históriáját, a' sok költeményektől meg tisztítva igen jól: melly História 1603-dik eszt.[endőben] megvólt az Istvánfi Miklós Vitzé-Palatinus Bibliotékájában; de hová lett az után, bizonytalan. Igen nagy kár, ha ugyan el-veszett, mivel igen jelesen vólt megírva, a'ki olvasta, ollyan tanubizonyságot tett rólla, hogy annál jobb Históriát a' Magyar dolgokra nem olvasott."

Szerencsére a mü nem veszett el, s egy kézirata Dóka Mihály Pozsony megyei szolgabíró jóvoltából Kovachich Márton Györgyhöz került, aki 1798-ban azt nyomtatásban megjelentette. A kézirat címoldala közli az olvasóval, hogy a „tizedik tized"-ről van szó, ezért Kovachich előszavában kifejtette: kívánatos volna, ha az előző tizedek is napvilágra kerülnének. Ezek azonban az elmúlt kétszáz évben nem bukkantak fel, s ma már bizonyossággal állíthatjuk, hogy azok valójában nem is készültek el.

Közel hét évtizeddel később viszont Toldy Ferenc a Budapesti Egyetemi Könyvtárban, Pray György kéziratgyüjteményében talált rá a történeti munka folytatására. Ez a kézirat a 10. tized hetedik könyvének 2 . fejezetétől indul, így a hetedik könyv 2-5. fejezetei mindkét kéziratban benne vannak, némi eltéréssel. Toldy 1866-ban adta ki mindkét kéziratot, mind a mai napig ez a mü legutolsó latin nyelvü kiadása. A bevezetőben Toldy Ferenc Baranyai Decsi János életrajzát és fennmaradt műveinek alapos ismertetését nyújtja, s ezt a bevezetőt egyes munkáiból vett, fontos és jellemző részleteket tartalmazó függelék egészíti ki. A publikációt megelőzően Toldy kiterjedt levelezést folytatott, hogy Baranyai Decsi lehetőleg minden munkáját megszerezze. Szólásgyüjteményét Szabó Károly küldte el részére Kolozsvárról 1864ben, de legkorábbi munkáját, az 1587-ben Wittenbergben kiadott útleírást ${ }^{5}$ Toldynak kitartó próbálkozásai ellenére sem sikerült fellelnie. Ennek az útleírásnak ma is csak egyetlen példánya ismeretes, amelyre Koncz József talált rá itt, Marosvásárhelyen, ${ }^{6}{ }_{s}$ amely ma a Teleki Tékában található.

1880-ban Szabó Károly gróf Bánffy Miklós bonchidai könyvtárában talált két levelet, amelyet Hunyadi Ferenc, Báthori Zsigmond erdélyi fejedelem orvosa írt Baranyai Decsi Jánosnak, és egyet, amelyet Decsi írt Hunyadinak. Ez a levél Decsi János életrajzához sok fontos adatot nyújt, és az e levélhez tartozó széljegyzet volt az első forrás, amelyböl halálának éve ismeretessé vált. A levelek eredeti latin szövegét és magyar fordítását Szabó Károly tette közzé. ${ }^{7}$ Koncz József is tisztában volt Decsi János levelének fontosságával, ezért Szabó

${ }^{3}$ Bod Péter: Magyar Athenas. Szeben 1766. 68-69.

${ }^{4}$ Baronyai Decsi János magyar históriája [1592-1598]. Közli Toldy Ferenc. Monumenta Hungariae Historica. Magyar Történelmi Emlékek. Második Osztály. Írók. 17. kötet. Pest 1866. V-LXXX. 1328.

5 Johannes Cz. Deczi: Hodoeporicon itineris Transylvanici, Moldavici, Rvssici, Cassvbii, Masovici, Prvssici, Borussici, Pomerani, Marchici \& Saxonici, exantlati 1587. Wittebergae, M.D. LXXXVII. (RMK III. 764.)

${ }^{6}$ Koncz József: A marosvásárhelyi Evang. Reform. Kollegium története. Különlenyomat a Kollegium 1883-1888. és 1894/95. iskolai évi Értesítőből. Marosvásárhely 1896. 18-23.

7 Szabó Károly: XVI. századi magyar tudósok levelei. Történelmi Tár 1881. 470-493. Magyar fordítását már 1880-ban megjelentette Szabó Károly: Adatok Decsi János életéhez. = Protestans Theologiai Könyvtár XIII. kötet, Magyar protestans egyháztörténelmi monographiák. Bp. 1880. 137-144. 
Károly fordítását közölte a marosvásárhelyi Református Kollégium történetével foglalkozó munkájában.

Berlász Jenő 1973-ban Zágrábban, a Jugoszláv Tudományos Akadémia Levéltárában megtalálta Baranyai Decsi János történeti műve első részének 1598-ból származó másolatát. ${ }^{8}$ Így több mint kétszáz évvel Bod Péter müvének megjelenése után bebizonyosodott, hogy Decsi történeti munkája valóban megvolt Istvánffy Miklós könyvtárában.

1942-ben jelent meg először magyarul Baranyai Decsi történeti munkájának első része Novák József fordításában. ${ }^{9}$ Az első figyelemre méltó elemzést Baranyai Decsi történeti mủvéről Bartoniek Emma nyújtotta 1975-ben, aki Decsi munkájának egyes részeit összehasonlította más egykorú történetírók munkáiból vett részletekkel. ${ }^{10} 1977$-ben jelent meg Kulcsár Péter fordításában a történeti munka folytatása, ${ }^{11} \mathrm{~s}$ végül 1982-ben, szintén Kulcsár Péter fordításában a teljes mű a fordító előszavával. Ebben olvasható először a Báthori Zsigmond erdélyi fejedelemhez írt ajánlás szövege magyarul. ${ }^{12}$

Hadd szóljak ehhez kapcsolódóan néhány szóban egyik saját kutatási eredményemről is. A történeti mű első teljes magyar nyelvű fordítása előszavában a fordító azt feltételezi, hogy a történeti munka ajánlását Baranyai Decsi 1601-ben írta volna Báthori Zsigmond fejedelemhez. Pedig ez a feltételezés több ellentmondást is magában rejt az ajánlás szövegével szemben. E hibás feltételezés magyarázata abban rejlik, hogy a fordító tévesen értelmezte az ajánlás egyik kifejezését: amikor Győr bevételéről esik szó, ezt Győrnek a magyarok által 1598-ban történt visszafoglalására való utalásként értelmezte, holott a szövegben Baranyai Decsi valójában Győrnek a törökök által 1594-ben történt elfoglalására gondolt. Az ajánlás korhatározó utalásai alapján megállapítható, hogy az 1596-ban készült, s hogy ehhez az ajánláshoz eredetileg az 1798-ban kinyomtatásra került rész tartozott. ${ }^{13}$

Az elmúlt évszázadok kutatási eredményei alapján Baranyai Decsi János történetírói munkásságát illetően a következő kép bontakozik ki előttünk:

${ }^{8}$ Berlász Jenő: Újabb információk Istvánffy Miklós tékájáról. Erdélyi analekták 1598-ból - A zágrábi Corvin-kódex. = Az Országos Széchényi Könyvtár Évkönyve. 1972. Bp. 1975. 215. A kolligátumról a 216-228. oldalakon ír.

9

9 Baranyai Decsi János: Báthori Zsigmond harcai a török ellen. Szemelvények »Magyar históriájából« (Monumenta Hungariae Historica. Scriptores 17. k. Pest 1866. a 12-282. lapokról). Latinból fordította Novák József. = Erdély öröksége. Erdélyi emlékírók Erdélyröl. II. kötet. Sárkányfogak 1572-1602. Szerk. Makkai László. Bevezette Cs. Szabó László. Bp. [é. n.] 87-136. A kiadás reprintje: Budapest 1993.

10

Bartoniek Emma: Fejezetek a XVI-XVII. századi magyarországi történetírás történetéböl. Bp. 1975. Baranyai Decsy (Csimor) Jánosról: 259-275.

11

Baranyai Decsi János: Magyar História. X. tized. X. könyv. 13-14. fejezet; XI. tized. I. könyv. 110. fejezet, II. könyv 1-9. fejezet. Kulcsár Péter fordítása. = Humanista történetírók. Magyar Remekírók. Bp. 1977. A szöveg a 438-484. o.-on, a jegyzetek az 1112-1120. o.-on találhatók.

${ }^{12}$ Baranyai Decsi János magyar históriája [1592-1598]. Fordította és a bevezetőt írta Kulcsár Péter. A jegyzeteket Bellus Ibolya állította össze. Bibliotheca Historica. Bevezetö: 5-26. Baranyai Decsi János emlékirata a magyar történelemröl: 27-394. Jegyzetek: 395-414.

13

Holler László: „Feljegyzések az erdélyi magyar történelemröl” Baranyai Decsi János történeti müvének keletkezési idejéröl és kéziratairól. Magyar Könyvszemle 117. évfolyam 2001. 3. sz. [Megjelenés alatt]. 
A magyar történelem iránti érdeklödését már az 1587-ben Wittenbergben kiadott útirajzában megmutató szerző a magyar történetírásra vonatkozó elveit és elképzeléseit jogi munkája előszavában fogalmazta meg. A nagy mühöz vázlatot készített, ezt nevezte „Annalium Hungaricorum"-nak, Magyar Évkönyvnek. Anyaggyüjtés után a Marosvásárhelyen töltött évei alatt a saját kora eseményeit tárgyaló rész kidolgozásához fogott, s az 1592 végétől 1594 végéig terjedő események leírását 1596 elején fejezte be. Munkáját ugyanekkor készült ajánlással 1596 áprilisa és júliusa között adta át Báthori Zsigmond erdélyi fejedelemnek, anélkül azonban, hogy a remélt elismerést és támogatást megkapta volna.

Erről nagy keserüséggel 1596. augusztus 16-án a fejedelem orvosához, Hunyadi Ferenchez az alábbiakat írja: ${ }^{14}$

„,...hogy más tudós férfiakat is hasonló nagy tettekre buzdítsak, meg hogy a fejedelem kegyét és támogatását is megnyerjem, serénységem más, kisebb alkotásain kívül két figyelemre méltó müvet ajánlottam fel minap a fenséges fejedelemnek, ezek közül az egyik Sallustius volt, én fordítottam le honi nyelvre...

S hogy a hivatali teendőimen felül körülbelül ötévi munkával összeszedett s csekély eröm szerint összeállított Magyar História nekem mennyi verítékembe került, arra tanúnak a jó Istent hívom, mert az emberek ítéletét a kelleténél igazságtalanabbnak tartom. Mikor a fenséges fejedelemnek ezt a fáradságos munkámat is bemutattam, s ezen a címen valami kis útiköltséget kértem, semmit nem értem el azok közül, amiket elérni óhajtottam. Mit tegyek tehát? Vajon azoknak ajánljam fel müveimet, akik nem igénylik, vagy ha ingyen elfogadják, el sem olvassák őket?”

Elkeseredettségében azt tervezte, hogy még az év öszén elhagyja Erdélyt. Kivándorlási terveit nem váltotta valóra, Székelyvásárhelyen maradt, ahol 1597. augusztus 26-án a helyi városvezetés döntése alapján, többévi tanítói munkája elismeréseként lakás céljára egy elhagyott iskolaépületet kapott. ${ }^{15}$

1596 végén, 1597 elején fogott hozzá munkájának folytatásához. Nem nyúlt a hetedik könyv hosszú 1 . fejezetéhez, kissé átjavította a 2, 3. és 4. fejezeteket, a legutolsó 5. fejezetet teljesen átírta, és új címmel látta el. Ezután folytatta az 1595. év eseményeinek elbeszélését. A 10. tizedet, amely az 1596 végéig történtekkel zárul, valószínüleg még 1597-ben befejezte.

Ebben az évben írta a törökök elleni harcra buzdító, hosszú magyar nyelvü énekét is, amely szándékosan a szerző neve nélkül jelent meg. Éppen ma jelenik meg Budapesten a Magyar Könyvszemle idei első száma, amelyben más müveivel való tartalmi összehasonlítás alapján igazolom, hogy a vers szerzője kétségtelenül Baranyai Decsi János. ${ }^{16}$

14 Hunyadi Ferenc levele Baranyai Decsi Jánosnak [1596]. Fordította Csonka Ferenc. = Janus Pannonius - Magyarországi humanisták. Magyar Remekírók. Bp. 1982. 801-803. - Baranyai Decsi János levele Hunyadi Ferencnek 1596. augusztus 16. Fordította Csonka Ferenc. 804-807.

${ }^{15}$ Adalék Décsi Czimor János életéhez. Közli Koncz József. Történelmi Tár 1881. 582-583., valamint Koncz József: A marosvásárhelyi Evang. Reform. Kollegium Története. Marosvásárhely 1896. 2123.

16 Holler László: Baranyai Decsi János törökök elleni harcra buzditó éneke 1597-böl. Magyar Könyvszemle 117. évfolyam, 2001. 1. szám. 101-112. 
Így szól a költő a vers végén:

Az ki ez verseket most igy öszue rendele,

Hogy hazaiat birya pogan, busul sziueben,

Kiuan Istentül valaha menni földeben.

$[\ldots]$

Ezer ötszaz es kilenczuen hét esztendöben,

Mikor az Törökrül gondolkodnec buaban,

Egy puszta Clastromban Szekelyec varasaban.

Ezeket a sorokat Baranyai Decsi pontosan ezen a helyen írta, ahol most állunk meghatódottan, több mint négy évszázad után. Ahol megemlékezünk a történetíróról, a fillozófusról, a műfordítóról, a jogtudósról és a históriás éneket szerző költőről, aki humanista müveltségét székelyvásárhelyi iskolamesterként e falak tövében igyekezett továbbadni a következő generációknak.

1598-ban számos más feladat megvalósításán dolgozott. Márciusban kelt Telegdi Jánoshoz írt levele a magyar rovásírásról, amelyet a címzett könyvének bevezetésében közzétett, és ekkor rendezte sajtó alá szólásgyüjteményét is. ${ }^{17}$ Az év elején készült el terjedelmes latin szózata Báthori Zsigmondhoz, ${ }^{18}$ s Toldy Ferenc joggal feltételezi, hogy a fejedelem 1598. április 10én elmondott búcsúbeszéde is Decsi János tollából fakadt. ${ }^{19}$

1598 végén fordult figyelme ismét történeti munkája felé. Megkezdve a 11. tizedet, az 1597. év eseményeit elég röviden érintve a következő év történéseinek tárgyalásába kezdett. Az 1598. év közepéig jutott el, mikor munkáját abbahagyta, s ezen a ponton szakad meg a korunkra jutott emlékiratának fonala.

És 400 évvel ezelőtt, 1601. május 15-én, negyvenes éveinek elején, a halálát említő feljegyzés alapján $^{20}$ feltehetően betegség következtében meghalt Decsi János, ,a legműveltebb férfiú, iskolájának dísze és ékessége", amiképpen az elhunytat kollégája, Piskolti Fabricius Mátyás marosvásárhelyi református prédikátor jellemezte. Baranyai Decsi János korai halála megfosztotta az utókort mind az 1598-at követő erdélyi eseményeknek egy, a törökök ellen megalkuvás nélküli harcot hirdető humanista nézőpontjából megírt hiteles történeti forrásától, mind a korábbi évszázadok történelmének az elődökétől eltérő szemléletü, nagy ívü feldolgozásától.

De ennek ellenére nagyon nagy érték az utókor számára a fennmaradt mü, amely a szemtanú és kortárs jólinformáltságával írja le a 16. század végének sorsdöntő eseményeit, emléket

17

„Adagiorvm Graecolatinovnqaricorvm Chiliades guinque. Bartphae 1598. (RMNY 815.) Fakszimile kiadás: Baranyai Decsi János: Adagiorvm Eötvös Loránd Tudományegyetem, Fontes ad Historiam Linguarum populorumque Uraliensium 5. Bp. 1978.

${ }^{18}$ Balázs Mihály - Monok István - Varga András - Tar Ibolya (ford.): Baranyai Decsi Jánosnak a török elleni háborúra buzdító beszéde 1598-ból. Lymbus Mủvelődéstörténeti Tár II. Szeged 1990. $37-100$.

${ }^{19}$ Baronyai Decsi János magyar históriája [1592-1598]. Közli Toldy Ferenc. Monumenta Hungariae Historica. Magyar Történelmi Emlékek. Második Osztály. Írók. 17. kötet. Pest 1866. XXXIV.

${ }^{20}$ Barts Gyula: Mikor halt meg Baranyai Decsi János? Irodalomtörténet IV. évfolyam, 3-4. füzet, 1915. március-április 146. 
állítva mind a törökök ellen vívott háború küzdelmeinek, mind az elismerésért küzdő polihisztor harcainak.

Emlékezzünk reá megbecsüléssel!

János Baranyai Decsi, the Historian. János Baranyai Decsi historical memoirs is an eyewitness' treatise of Transylvanian history from the end of 1592 till the middle of 1598. The present lecture gives an overview on how the manuscripts of this work came to light durring the last two centuries and how our knowledge improved about it. By his own research the lecturer corrects some former ideas on the dating of the historical work. Analyzing the text of the dedication to Zsigmond Báthori, Prince of Transylvania and Baranyai Decsi's correspondence with the physician of the Prince, it can be established that the first part of the memoirs discussed the events till the end of 1594 and it was dedicated to the Prince in 1596. The second part was written 1597 onwards. More details can be found in the lecturer's paper appearing in the 2001/3 issue of Magyar Könyvszemle. The lecture finally gives a chronological account of Baranyai Decsi's last few years with special emphasis of his historical treatise. 